\title{
AUTOCHTHONOUS BALKAN GOAT BREED - COMPOSITION AND TRAITS OF KID CARCASS
}

\author{
M. Žujović ${ }^{1}$, N. Stanišić ${ }^{1}$, N. Memiši ${ }^{2}$ \\ ${ }^{1}$ Institute for Animal Husbandry, 11080, Belgrade-Zemun, Republic of Serbia \\ ${ }^{2}$ AD Mlekara, Subotica, Republic of Serbia \\ Corresponding author: zotom@mail.com \\ Invited paper
}

\begin{abstract}
Investigations were realized within the program of protection of genetic resources of autochthonous goat breeds - Balkan goat breed. Trial was carried out on farms of individual producers, breeders on the territory of Svrljig region, on 12 male kids of average age of 63 days and average body mass prior to slaughtering of $10,54 \mathrm{~kg}$. Objective of the research was to determine the meat yield (dressing percentage), share of by products of in body mass prior to slaughtering and in processed carcass, commercial value of carcass (by evaluation of conformation, covering of carcass and kidneys with fat tissue, colour of meat and tallow) and share of main carcass parts. Results of the research indicated that kids of Balkan goat breed at stated age have average body mass of $10,54 \mathrm{~kg}$ and yield of warm carcass with head and giblets of $58,89 \%$, which is high value and is within the limits for yield realized by kids of approximate age of pure goat breeds. Shares of slaughter by products (rumen, small intestines, skin, abomasus), giblets (liver, lungs, heart, spleen, kidneys), fat tissue (peritoneum, kidney, mesentherium) and head in cooled carcass are also within the limits realized by kids of pure goat breeds. Commercial value of carcass, established based on assessment of conformation (scored as good), covering of carcass and kidneys with fat tissue (scored as medium), colour of meat and tallow (scored as very good) is good and within the values realized by kids of pure goat breeds. Quality of carcass evaluated based on share of main carcass parts of category I (thigh, loin part) of $33,41 \%$, category II (back, shoulder, neck) of 38,68\% and category III (breast, second fore thigh, second thigh) of $26,91 \%$, was very good. Muscle, fat and binding tissue (meat in narrow sense) made $2 / 3$, whereas bones made $1 / 3$ of the mass of three rib cut, which is also very good. Ratio of muscle and fat tissue was also very favourable - 5,08.
\end{abstract}

Key words: kids, carcass mass, meat yield, slaughter yield, giblets, carcass evaluation, carcass composition, tissue ratio 


\section{Introduction}

Kid meat is very important in human nutrition, especially in poor countries, although in the last decades, due to its high biological value, the demand for this meat is increasing even in countries of high standard of living. Production of kid meat was not in focus of attention in Serbia in past several decades, especially after the World War II in former Yugoslavia, breeding of goats was forbidden. However, starting from the seventies of the last century, interest in goat breeding is increasing, and their number is constantly increasing, and slaughter kids are sold on the market, mainly light kids $(8-12 \mathrm{~kg})$, rarely somewhat heavier kids (above $15 \mathrm{~kg}$ ).

In scientific literature there are almost no data relating to quality of carcass of kids of Balkan autochthonous breeds. Fehr et al. (1975) investigated the effect of age (from 56 to 166 days) at slaughtering on slaughter yield of Alpina kids and established that older kids, i.e. kids of greater body masses, resulted in statistically significantly lower yield. Morand - Fehr et al. (1985) established that in the carcass of kids of Alpina and Saanen breed (slaughtered with body masses of 8, 10, $12,14,18$ and $24 \mathrm{~kg}$ ) the amount of fat tissue increased with the increase of body mass at slaughtering. Žujović et al. $(1983,1988,2007)$ stated data according to which kids of Domestic improved goat at the age of 2 months reach average body mass of approx. $10 \mathrm{~kg}$ and average yield of warm carcass with giblets of approx. 59\%. Žujović et al. (1984) established that in carcasses of kids of Domestic improved goat of average body mass at slaughtering of $10,79 \mathrm{~kg}$, there was $8,27 \%$ intermuscular fat tissue and $59,50 \%$ of muscle tissue. Ćeranić et al. (1981) established that average body mass of kids of Domestic White goat at the age of 60 days was approx. 13,21 kg. Ceranić (1984) stated that kids of Domestic Balkan goat at the age of 60 days realized body mass of approx. $10 \mathrm{~kg}$. Sanz-Sampelayo et al. (1987) stated data on quantity of tissues (muscle, fat and bone) in the carcass and main parts (thigh, shoulder and back) of Granadiana breed kids.

Authors established that the amount of muscle and fat tissue increased, and amount of bones decreased, with the increase of age of animals. Chanin et al. (1990) stated that kids of large goat breeds realize better yields. In regard to the effect of breed, Samini et al. (1988) stated data on yield of kids of Barbari and Jamnapari goat breeds and concluded that breed had no significant effect on yield. Žujović et al. $(1998,2000)$ established that lighter kids, crosses of Domestic White goat breed and Saanen breed, compared to heavier kids had higher yield. Marković (1997) established in kids of Red and Spotted Balkan goat at the age of approx. 90 days average body mass of approx. $11 \mathrm{~kg}$. Žujović et al. $(2006,2008)$ stated that heavier kids had more favourable carcass evaluation in regard to conformation, covering of carcass and kidneys with fat tissue, colour of meat and tallow compared to lighter kids. 


\section{Materials and Methods}

Investigations were realized within the program of protection of genetic resources of autochthonous goat breeds. Trial was carried out on farm of individual producer-breeder in Svrljig region, on 12 male kids of Balkan breed, average age of 63 days and average body mass prior to slaughtering of $10,54 \mathrm{~kg}$. At slaughtering, mass was measured before slaughtering, mass of warm carcass with giblets, skin, fore stomach, small intestines and abomasus, which had previously been freed of the content and large intestines (free of content and washed), front thighs (cut in carpal joint) and hind thighs (cut in tarsal joint), mesentherium, as well as trachea, sex organs and horns. Subsequent to cooling (which lasted $18-20$ hours, on 2 to $4^{0} \mathrm{C}$ ), mass of cooled carcass was measured and carcasses were evaluated visually, their conformation, covering of carcass and kidneys with fat tissue, as well as colour of meat and tallow. Scoring system was from 1 to 5, where the highest mark designated the best traits. Subsequently, heads, giblets and fat tissue were measured, as well as mass of carcasses without heads and giblets. Carcasses were cut into sides along the spine, but tail remained on the right carcass side. After cutting of the carcass into sides, carcass sides were measured/weighed and cut into main carcass parts according to Rulebook on quality of meat from slaughter livestock, poultry and wild game, Official Journal of SFRY, No. 34/74. Three rib cut, which included $9^{\text {th }}, 10^{\text {th }}$ and $11^{\text {th }}$ rib, was separated from the back, and dissected in order to separate tissues, muscle, fat, binding and bone tissues. Obtained data were categorized and processed and mean values were calculated based on statistical indicators, as well as standard deviation and variation coefficient.

\section{Results and Discussion}

Results of the investigation showed that kids of Balkan goat breed at the age of two months realized average body mass of $10,54 \mathrm{~kg}$, average yield of warm carcass with head and giblets of $58,89 \%$, average yield of cooled carcass with head and giblets of $56,26 \%$ and average yield of cooled carcass without head and giblets of $42,81 \%$ (Table 1). Results of investigation are in concordance with results stated by Žujović et al. (1983) for kids of Domestic improved goat, as well as Samini et al. (1988) for kids of Barbari and Jamnapari breeds. Based on obtained results and literature data it can be concluded that in regard to observed traits, kids of Balkan goat breed realize same or approximately same results as kids of pure goat breeds at the approximately same age. 
Table 1. Average age and body mass at slaughtering, carcass mass and yield of kids of Balkan goat breed

\begin{tabular}{|l|c|c|c|c|}
\hline \multicolumn{1}{|c|}{ Indicator } & $\mathrm{X}$ & $\min -\max$ & $\mathrm{Sd}$ & $\mathrm{Cv}$ \\
\hline Age (days) & 63.00 & $51-81$ & 9.1917 & 14.59 \\
Body mass (kg) prior to slaughtering & 10.54 & $8.8-12.5$ & 0.1838 & 11.23 \\
Mass(kg) of warm carcass with giblets & 6.20 & $5.38-7.76$ & 0.0820 & 13.22 \\
Yield (\%) of warm carcass with giblets & 58.89 & $52.40-62.96$ & 0.3875 & 6.58 \\
Mass(kg) of cooled carcass with giblets & 5.93 & $5.09-7.39$ & 0.7758 & 13.09 \\
Yield (\%) of cooled carcass with giblets & 56.26 & $50.08-61.58$ & 3.7384 & 6.65 \\
Mass (kg) of cooled carcass without head and giblets & 4.51 & $3.74-5.57$ & 0.6488 & 14.38 \\
Yield(\%) of cooled carcass without head and giblets & 42.81 & $37.45-47.77$ & 3.4312 & 8.02 \\
Cooling loss (\%) & 4.47 & $3.72-4.72$ & 0.4054 & 9.07 \\
\hline
\end{tabular}

Table 2. Share of by-products of slaughtering of kids of Balkan goat breed, average body mass prior to slaughtering $10.54 \mathrm{~kg}$

\begin{tabular}{|l|c|c|c|c|}
\hline \multicolumn{1}{|c|}{ Indicator } & Weight $(\mathrm{kg})$ & $\mathrm{X}$ & (\%) min - max & CV \\
\hline Edible giblets & 0.242 & 2.32 & $1.25-3.41$ & 24.30 \\
\hline Rumen (empty) & 0.324 & 3.08 & $2.00-3.88$ & 19.19 \\
Small intestines (empty) & 0.566 & 5.40 & $3.92-7.16$ & 18.90 \\
Total edible giblets & \multicolumn{5}{l|}{} \\
\hline Giblets in the carcass & 0.248 & 2.33 & $1.74-2.78$ & 19.75 \\
\hline Liver & 0.216 & 2.05 & $1.43-2.52$ & 18.36 \\
Lungs & 0.054 & 0.51 & $0.41-0.60$ & 11.80 \\
Heart & 0.028 & 0.27 & $0.20-0.33$ & 18.76 \\
Spleen & 0.058 & 0.33 & $0.40-0.67$ & 15.28 \\
Kidneys & 0.604 & 5.49 & $4.95-6.13$ & 16.96 \\
Total giblets in the carcass & \multicolumn{3}{|l}{} \\
\hline Fat tissue & 0.055 & 0.53 & $0.14-1.32$ & 71.52 \\
\hline Kidney & 0.062 & 0.58 & $0.24-1.25$ & 32.00 \\
Peritoneum & 0.100 & 0.96 & $0.20-2.58$ & 51.90 \\
Mesentherium & 0.217 & 2.07 & $1.11-3.87$ & 45.84 \\
Total fat tissue & 0.504 & 5.23 & $4.88-5.80$ & 4.23 \\
\hline Head & 0.856 & 8.18 & $5.32-14.33$ & 25.23 \\
Skin & 0.079 & 0.80 & $0.59-1.02$ & 19.96 \\
Abomasus (empty) & 0.569 & 5.46 & $2.83-8.05$ & 14.34 \\
Waste (lower thighs, omasus) &
\end{tabular}


Shares of slaughter by products, such as edible giblets (rumen, small intestines), also giblets which are component of the carcass (liver, lungs, heart, spleen, kidneys), fat tissue as part of the carcass (kidney, peritoneum, mesentherium), head, skin and abomasus (Table 2), were favourable and within values realized for same traits by kids of pure breeds. Similar results were also obtained by Morand - Fehr et al. (1985).

Shares of head, giblets (liver, lungs, heart, spleen, kidneys) and fat tissue (kidney, peritoneum, mezentherium) in cooled carcass of kids of Balkan breed (Table 3 ) were satisfactory and within values obtained in pure breed kids.

Table 3. Mass and share of head, giblets and fat tissue in cooled carcass of kids of Balkan goat breed average weight of $5.93 \mathrm{~kg}$

\begin{tabular}{|l|c|c|c|c|}
\hline \multicolumn{1}{|c|}{ Indicator } & $\mathrm{kg}$ & $\mathrm{X}$ & $(\%) \min -\max$ & $\mathrm{Cv}$ \\
\hline Head & 0.504 & 9.45 & $8.55-10.73$ & 8.34 \\
\hline Giblets & & & & \\
\hline Liver & 0.248 & 4.17 & $3.19-6.85$ & 20.65 \\
Lungs & 0.216 & 3.63 & $2.82-4.49$ & 16.64 \\
Heart & 0.054 & 0.92 & $0.72-1.14$ & 11.60 \\
Spleen & 0.028 & 0.47 & $0.36-0.57$ & 14.24 \\
Kidneys & 0.058 & 0.97 & $0.74-1.20$ & 11.73 \\
Total giblets & 0.604 & 10.16 & $9.46-12.06$ & 8.06 \\
\hline Fat tissue & & & & \\
\hline Kidney & 0.062 & 1.04 & $0.45-2.22$ & 31.34 \\
Peritoneum & 0.055 & 0.94 & $0.14-2.27$ & 71.01 \\
Mesentherium & 0.100 & 1.73 & $0.34-4.75$ & 54.14 \\
Total fat tissue & 0.217 & 3.78 & $2.14-7.13$ & 44.35 \\
\hline
\end{tabular}

Measures taken on carcass and carcass sides, fat tissue thickness, evaluation of carcass based on conformation and covering of carcass and kidneys with fat tissue, colour of meat and tallow (Table 4) were satisfactory and within values determined in kids of pure breeds at the same age. 
Table 4. Measures on carcass and carcass sides and evaluation of the carcass of kids of Balkan goat breed

\begin{tabular}{|c|c|c|c|c|}
\hline Indicators & $\mathrm{X}$ & $\min -\max$ & $\mathrm{Sd}$ & $\mathrm{Cv}$ \\
\hline \multicolumn{5}{|l|}{ Carcass measures $(\mathrm{cm})$} \\
\hline Calcaneum - Ischium & 23.09 & $22.0-25.0$ & 0.9328 & 4.04 \\
\hline Last sacral vertebrae - neck & 43.46 & $40.0-48.0$ & 2.5902 & 5.96 \\
\hline Last sacral vertebrae - atlas & 59.79 & $56.0-69.0$ & 3.0971 & 5.18 \\
\hline Articulatio gerus - shoulder joint & 56.92 & $52.0-70.0$ & 6.1474 & 10.80 \\
\hline Width of both thighs & 10.17 & $9.0-12.0$ & 0.8441 & 8.30 \\
\hline Breast width & 9.71 & $8.5-12.5$ & 1.1836 & 12.19 \\
\hline Breast depth & 18.37 & $16.0-21.0$ & 1.5008 & 8.17 \\
\hline Breast circumference & 49.04 & $45.0-54.0$ & 3.1140 & 6.35 \\
\hline \multicolumn{5}{|l|}{ Carcass side measures $(\mathrm{cm})$} \\
\hline Pubis - Articulatio gerus & 14.37 & $12.0-16.0$ & 1.0116 & 7.04 \\
\hline Pubis - Calcaneum & 26.88 & $25.0-30.0$ & 1.7418 & 6.48 \\
\hline Pubis - I rib & 47.84 & $44.0-54.0$ & 3.0187 & 6.31 \\
\hline Pubis - atlas & 59.34 & $56.0-65.0$ & 3.0382 & 5.12 \\
\hline Thigh circumference & 24.42 & $22.0-27.0$ & 1.5849 & 6.49 \\
\hline \multicolumn{5}{|l|}{ Thickness $(\mathrm{mm})$ of fat tissue } \\
\hline On breast & 4.34 & $2.0-7.0$ & 1.8510 & 42.65 \\
\hline Above back muscle & 1.45 & $1.0-3.0$ & 0.1923 & 13.26 \\
\hline On the side & 2.10 & $1.0-4.0$ & 0.4429 & 21.09 \\
\hline \multicolumn{5}{|l|}{ Carcass evaluation } \\
\hline Conformation (points)* & 3.38 & $1.0-4.5$ & 0.8697 & 25.73 \\
\hline Covering with fat tissue (points $* *$ & 3.96 & $3.0-5.0$ & 0.7785 & 19.66 \\
\hline Covering of kidneys with fat tissue $(\%)^{* * *}$ & 50.42 & $15.0-100.0$ & 32.9747 & 65.40 \\
\hline Meat colour (points) ${ }^{* * * *}$ & 4.09 & $3.0-5.0$ & 0.6442 & 15.75 \\
\hline Tallow colour (points) $* * * * *$ & 4.25 & $3.5-5.0$ & 0.4327 & 10.18 \\
\hline
\end{tabular}

*Evaluation: very good -5 ; good -4 ; medium -3 ; poor -2 ; bad -1 .

** Evaluation: equal, tallow thickness up to $5 \mathrm{~mm}-5$; partially no tallow, tallow thickness up to $5 \mathrm{~mm}-$ 4; large areas without tallow - 3; substantial areas without tallow and tallow thicker than $5 \mathrm{~mm}-2$; carcass almost without tallow, tallow thickness up to $1 \mathrm{~mm}-1$.

*** Evaluation: $100 \%$-kidney completely covered with tallow; $75 \%$ - approx. $2 / 3$ of kidney covered with tallow; $50 \%$ - approx. $1 / 2$ of kidney covered with tallow; $25 \%$ - approx. $1 / 4$ of kidney covered with tallow.

**** Evaluation: light red -5 ; pink -4 ; light pink -3 ; pale pink -2 ; dark -1 .

$* * * * *$ Evaluation: white -5 ; cream -4 ; reddish -3 ; red-cream -2 ; yellow-red -1 .

Share of carcass (carcass side) of category I (thigh, loin part) was 33,41\%, of category II (back, shoulder, neck) 38,68\% and category III (breast, second fore thigh/cannon, second thigh/cannon) 26,91\% (Table 5). 
Table 5. Mass and share of main carcass parts in carcass sides of kids of Balkan goat breed

\begin{tabular}{|l|c|c|c|c|}
\hline \multicolumn{1}{|c|}{ Indicators } & $\mathrm{kg}$ & $\mathrm{X}$ & $(\%) \min -\max$ & $\mathrm{Cv}$ \\
\hline Mass of right carcass side & 2.283 & - & - & 14.53 \\
Mass of left carcass side & 2.207 & - & - & 14.62 \\
\hline Parts of carcass side (left) & & & & \\
\hline Thigh & 0.537 & 24.27 & $22.03-28.43$ & 5.57 \\
Loin section & 0.203 & 9.17 & $7.78-10.49$ & 11.82 \\
Total category I parts & 0.740 & 33.41 & $31.18-38.25$ & 5.43 \\
Back & 0.213 & 9.61 & $8.22-11.69$ & 12.86 \\
Shoulder & 0.429 & 19.36 & $15.55-22.69$ & 14.16 \\
Neck & 0.217 & 9.71 & $7.33-11.69$ & 10.97 \\
Total category II parts & 0.859 & 38.68 & $34.51-42.52$ & 7.75 \\
Breast with second fore thigh/cannon & 0.426 & 19.60 & $15.59-25.06$ & 17.46 \\
Second thigh/cannon, hind & 0.160 & 7.32 & $4.29-9.02$ & 13.13 \\
Total category III parts & 0.586 & 26.91 & $19.29-31.58$ & 12.66 \\
\hline
\end{tabular}

According to shares of tissues in three rib cut (Table 6), the highest share (approx. 52\%) had the muscle tissue, significantly less (approx. 10\%) fat tissue and $3,62 \%$ binding tissue, in total $66 \%$ of meat in broader sense. Share of bones was $24,76 \%$.

Table 6. Share and ratio of tissues in three rib cut of kids of Balkan goat breed

\begin{tabular}{|l|c|c|c|c|}
\hline \multicolumn{1}{|c|}{ Indicator } & $(\mathrm{g})$ & $\mathrm{X}$ & $(\%)$ min-max & $\mathrm{Kv}$ \\
\hline Mass of three rib cut & 91.98 & - & - & 38.41 \\
\hline Share of tissues in three rib cut & & & & \\
\hline Muscle & 52.29 & 56.94 & $40.35-63.91$ & 10.77 \\
Fat & 10.30 & 10.53 & $5.50-16.77$ & 33.56 \\
Binding & 3.62 & 4.01 & $1.86-5.56$ & 21.41 \\
Total soft tissue & 66.21 & 71.48 & $56.13-82.27$ & 9.76 \\
Bones & 24.76 & 26.80 & $17.19-35.56$ & 17.89 \\
\hline Tissue ratio & & & & \\
\hline Muscle - fat & 5.08 & - & $2.48-11.19$ & 43.35 \\
Muscle - bone & 2.11 & - & $1.03-3.72$ & 29.51 \\
Fat - bone & 0.42 & - & $0.16-0.85$ & 45.06 \\
\hline
\end{tabular}

\section{Conclusion}

Based on results obtained in the investigation of yield of meat, evaluation of carcass and carcass composition of kids of Balkan goat breed at the age of 2 months, the following can be concluded: 
- Values of yield of warm and cooled carcass with head and giblets and yield of cooled carcass without head and giblets were very good and within values realized by kids of pure goat breeds;

- Shares of edible giblets, giblets within the carcass, head, fat tissue and skin were also within values realized by kids of pure goat breeds;

- Evaluation of carcass in regard to conformation, covering of carcass and kidneys with fat tissue, colour of meat and tallow was good;

- Shares of main carcass parts was favourable since $2 / 3$ of carcass consisted of category I and II parts;

- Muscle, fat and binding tissue (meat) made $2 / 3$ of the carcass;

- Very favourable ratio of muscle and fat tissue.

\title{
Acknowledgment
}

This research is part of the Project TR 20005 financial supported by Ministry of Science and Technological Development of the Republic Serbia.

\section{Autohtona balkansa rasa koza - sastav i osobine jarećeg trupa}

\author{
M. Žujović, N. Stanišić, N. Memiši
}

\section{Rezime}

Ispitivanja su obavljena $\mathrm{u}$ okviru programa zaštite genetskih resursa autohtonih rasa koza - balkanske rase. Ogled je izveden kod individualnih odgajivača na području Svrljiškog regiona, na 12 muških jaradi prosečnog uzrasta 63 dana i prosečne telesne mase pred klanje od 10,54 kg. Cilj ispitivanja je bio da se utvrdi prinos mesa (randman), udeo pratećih proizvoda klanja u trupu pred klanje i u ohlađenom trupu, komercijalna vrednost trupa (ocenom konformacije, prekrivenosti trupa i bubrega masnim tkivom, boje mesa i loja) i udeo osnovnih delova trupa. Rezultati ispitivanja ukazuju da jarad balkanske koze u navedenom uzrastu imaju prosečnu telesnu masu od $10,54 \mathrm{~kg}$ i randman toplog trupa sa glavom i iznutricama od $58,89 \%$, što predstavlja visoku vrednost i nalazi se u granicama vrednosti randmana koji postižu jarad približnog uzrasta plemenitijih rasa koza. Udeo pratećih proizvoda klanja (burag, tanka creva, koža, sirište), iznutrica (jetra, pluća, srce, slezina, bubrezi), masnog tkiva (peritoneum, bubrežno, opornjak) i glave u ohlađenom trupu su takođe u granicama koje postižu jarad plemenitijih rasa koza. Komercijalna vrednost trupa, utvrđena na osnovu ocene 
konformacije (ocenjena je kao povoljna), prekrivenosti trupa i bubrega masnim tkivom (ocenjena je kao osrednja), boje mesa i loja (ocenjene su kao veoma povoljne) je dobra i u okviru vrednosti koju imaju jarad plemenitijih rasa koza. Kvalitet trupa, procenjen na osnovu udela osnovnih delova trupa I kategorije (but, slabinski deo) od 33,41\%, II kategorije (leđa, plećka vrat) od 38,68\% i III kategorije (grudi, podlaktica potkolenica) od 26,91\%, je veoma povoljan. Mišićno, masno i vezivno tkivo (meso u užem smislu) čini $2 / 3$, dok kosti čine $1 / 3$ mase trorebarnog isečka, što je veoma povoljno. Odnos mišićnog i masnog tkiva je takođe povoljan i iznosi 5,08.

\section{References}

CHANIN K.A., MOUD M. (1990): Commercial carcass characteristics and carcass measurements in fench Alpine, Rove and Alpinecrossbred male goats. Indian J. Anim. Sci., 60, 6, 709.

ĆERANIĆ V., ŽUJOVIĆ M., JOSIPOVIĆ S. (1981): Caracteristiques de la chevre blanche du pays, 32 Annual Meeting, EAAP, Zagreb.

ĆERANIĆ V. (1984): Kozarstvo. Biblioteka »Male farme« Beograd.

FEHR P.M., SAUVANT D., HERVIEN J., DELAGE J., (1975): Influence des methodes $\mathrm{d}^{\prime}$ alimentation et de 1 'age a 1 'abatage sur performances des chevreaux males. E.A.A.P. Varšava.

MARKOVIĆ B. (1997): Proizvodne i reproduktivne osobine važnijih varijeteta domaće balkanske koze u Crnoj Gori. Magistarski rad. Poljoprivredni fakultet, Beograd - Zemun.

Pravilniku o kvalitetu mesa stoke za klanje, peradi i divljači. Sl.list SFRJ, 34, 74.

MORAND - FEHR P., BAS P., ROUZEAU A., HERVIEU J. (1985): Development and characteristics of adipose deposits in male kids during growth from birth to weaning. Animal Production, 41, 3.

SAMINNI A.L, KHAN B.M., KHUB S. (1988): Growth performance of goats underthree system of feeding management. Indian Animal Sci., 58, 2.

SANZ - SAMPELAYO M.R., MUNOZ F.J., LARA L., GIL EXTREMERA F., BOZA J., (1987): Factor affecting pre and post weaning growth and body composition in kid goats of the Granadiana breed. Animal Production, 45, 2.

ŽUJOVIĆ M., JOSIPOVIĆ S. (1983): Uticaj telesne mase jaradi pored klanje na prinos i kvalitet mesa. Kvalitet mesa i standardizacija, Bled.

ŽUJOVIĆ M., JOSIPOVIĆ S., TOMIĆ Z., PETROVIĆ M., IVANOVIĆ S. (2006): Telesna masa jaradi pred klanje kao faktor prinosa i kvaliteta mesa. II Uticaj telesne mase jaradi pred klanje na ocenu trupa. Stočarstvo, veterinarstvo i agroekonomija, Herceg Novi.

ŽUJOVIĆ M., ĆERANIĆ V., JOSIPOVIĆ S. (1984): Značaj i osobine jarećeg mesa. VII republičko savetovanje, Banja Koviljača. 
ŽUJOVIĆ M. (1988): Oplemenjivanje populacije koza gajenih na farmi "Bačevsko polje" u Dimitrovgradu. Magistarski rad. Poljoprivredni fakultet. Beograd Zemun.

ŽUJOVIĆ M., JOSIPOViĆ S., PETROVIĆ. P.M., VLAHOVIĆ M., STRSOGLAVEC S., (1998): Uticaj telesne mase na prinos i sastav trupa i kvalitet mesa jaradi domaće bele koze i njenih meleza, Tehnologija mesa, 6, 259-234.

ŽUJOVIĆ M., JOSIPOVIĆ S., TOMIĆ Z., STANIŠIĆ N., NEŠIĆ Z. (2008): Prinos mesa jaradi srpske bele koze u zavisnosti od telesne mase pre klanja, Biotechnology in Animal Husbandry, 5-6, 61-69.

ŽUJOVIĆ M., JOSIPOVIĆ S., TOMIĆ Z., PETROVIĆ M.P., IVANOVIĆ S., PETROVIĆ M. (2007): Telesna masa jaradi pred klanje kao faktor prinosa i kvaliteta mesa. II Uticaj telesne mase jaradi pred klanje na ocenu trupa, Savremena poljoprivreda, 3-4, 47-52.

ŽUJOVIĆ M., JOSIPOVIĆ S., GLUHOVIĆ M., STRSOGLAVEC S., TOMAŠEVIĆ D. (2000): Telesna masa jaradi domaće bele koze pred klanje kao faktor prinosa i kvaliteta mesa, Journal of scientific agriculture research, 213, 113120 . 